of such a procedure. These tended to be the women who when approached by our nurses were adamant in the manner of their refusal, and some even went so far as to refuse to discuss the subject. A less extreme example came in the form of ambivalance, when a patient would approve the principles of screening for carcinoma of the cervix but would not herself undergo such a test.

Apathy is perhaps the most difficult of human failings to counter and is almost worthy of the term the "eighth deadly sin." The patient who after listening to the nurse agreed to attend but did not do so presented a formidable problem, for when she was revisited there always seemed to be some plausible explanation for her default. There appeared to be a regiment of women waiting patiently at home each Tuesday and Wednesday for a mythical tradesman to call.

In an analysis of the results of six and a half years' work of the cervical cytology service in Great Britain, Thomson (1971) concluded that the rate for both doubtful and abnormal smears was $7 \cdot 1$ per 11,000 women. On this basis 600 women would have produced fewer than five abnormal smears, or put another way 16 abnorma smears would have been expected from 2,300 women. The survey figures were about three and a half times those of the national figures.

Some of the difference can be explained in terms of the response rate from the different social groups. Analysing the results of 38,741 cases, Wakefield (1971) commented that "there is still a gross over-representation in the screened population of women married to professional, managerial and skilled workers (social classes I, II and III) and a very serious under-representation of the women most vulnerable to cervical cancer (social classes IV and V) when the proportion of each class examined is compared with the proportion of each in the population at large."

\section{Conclusions}

If our experience that a high incidence of abnormal cervical smears (26 per 1,000 found when screening most women in one practice) can be repeated in other areas it suggests that a more positive approach must be made to the women at risk. By reason and by persistence women, particularly those in the lower social groups, must be persuaded to come forward. Such an approach must be made in a personal manner and be followed up, if necessary, by a personal interview.

I should like to thank Dr. G. S. Cruickshank for his practical help, Mr. I. K. Mathie, gynaecologist, for his encouragement and for undertaking the investigation of the patients found to have abnormalities, Dr. E. Walton, consultant pathologist, for his advice and for reporting on so many slides, Mrs. Enid Young, who organized so admirably the administration, and Carol Otterburn and Ann Ford, who undertook the follow-up of the patients.

\section{References}

Thomson, J. G. (1971). Health Trends, 3, 24. Wakefield, J. (1971). Health Trends, 3, 25.

\title{
Endocrine Response to Substitution of Corticotrophin for Oral Prednisolone in Asthmatic Children
}

\author{
D. N. S. MALONE, J. C. DREVER, I. W. B. GRANT, I. W. PERCY-ROBB
}

British Medical fournal, 1972, 3, 202-205

\section{Summary}

The hypothalamo-pituitary-adrenal axis has been assessed in 17 asthmatic children before and after long-term prednisolone therapy was changed to daily corticotrophin. In 14 of the 17 children the plasma corticosteroid concentration exceeded $15 \mu \mathrm{g} / 100 \mathrm{ml}$ within five days of starting corticotrophin. No exacerbation of asthmatic symptoms occurred during conversion. The plasma corticosteroid response to insulin-induced hypoglycaemia was normal in four children about six weeks after conversion to corticotrophin, took up to 36 months to become normal in nine, and remained abnormal in one child throughout the period of the trial.

Department of Medicine, Western General Hospital, Edinburgh 4 D. N. S. MALONE, M.B., M.R.C.P., Senior Registrar

Department of Paediatrics, Royal Hospital for Sick Children, Edinburgh 9

J. C. DREVER, M.B., D.OBST.R.C.o.G., Registrar (At present: General Practitioner, Dalkeith, Midlothian)

Respiratory Diseases Unit, Northern General Hospital, Edinburgh 5, and University Department of Respiratory Diseases, City Hospital, Edinburgh 10

I. W. B. GRANT, M.B., F.R.C.P., Consultant Physician

Department of Clinical Chemistry, the Royal Infirmary, Edinburgh 3 I. W. PERCY-ROBB, M.B., M.R.C.PATH., Senior Lecturer

\section{Introduction}

During the past few years there has been a trend towards the use of corticotrophin or its synthetic analogues in preference to oral steroids in the management of bronchial asthma.

The basis of this trend is that the use of corticotrophin is a more physiological form of therapy (Schwarz, 1959), in that the plasma concentration of adrenal corticosteroid can be raised to therapeutic levels without suppression of adrenocortical function. However, the effect of substituting corticotrophin for long-term oral steroid therapy on the hypothalamo-pituitary components of the hypothalamo-pituitary-adrenal axis is not well documented. It has been shown that a normal plasma fluorogenic corticosteroid response to insulin-induced hypoglycaemia is maintained in patients treated with corticotrophin for up to two years, but these patients had not previously received oral steroid (James, 1970).

The conversion of a patient from a long-term oral steroid regimen to long-term corticotrophin therapy is not entirely without risk. Serious adrenocortical insufficiency may occur during conversion to corticotrophin and the risk of status asthmaticus developing in patients who are weaned from oral steroid is recognized (Maunsell et al., 1968). Patients who are given corticotrophin may develop hypersensitivity reactions and must suffer the discomfort of repeated injections.

An advantage of the use of cortocotrophin was shown by Friedman and Strang (1966), who drew attention to the fact that the severe growth retardation commonly produced in asthmatic children by oral steroid could be minimized by substitution with corticotrophin. 
The investigation reported here was undertaken to assess the function of the hypothalamo-pituitary-adrenal axis in a group of asthmatic children in whom it had been decided to substitute corticotrophin for long-term prednisolone because of severe growth retardation. The effects on growth will be the subject of a separate communication. In addition, the effectiveness of long-term corticotrophin therapy in controlling asthmatic symptoms was assessed by comparing the length of time spent in hospital before and after substitution.

\section{Patients and Methods}

Seventeen children suffering from bronchial asthma were studied. The age and sex distribution is shown in Table $I$ and details of the duration and method of administration of prednisolone are given in Table II. The mean dose of prednisolone was $9 \cdot 3$ (range $5-20$ ) $\mathrm{mg} /$ day. All patients were admitted to

TABLE I-Age and Sex Distribution

\begin{tabular}{ll|c|c|c}
\hline & & Male & Female & Total \\
\hline $\begin{array}{l}\text { Number (years) } \\
\text { Mean age (year }\end{array}$ & $\cdots$ & $12(7-16)$ & $10 \cdot 1(6-16)$ & 17 \\
\hline
\end{tabular}

TABLE II-Type and Duration of Prednisolone Therapy

\begin{tabular}{ll|c|c|c|c|c}
\hline & \multicolumn{4}{|c|}{ Prednisolone } & \multirow{2}{*}{ Total } \\
\cline { 2 - 5 } & \multicolumn{3}{|c|}{ Daily } & $\begin{array}{c}\text { Alternate } \\
\text { Days }\end{array}$ & \\
\hline $\begin{array}{l}\text { Time in months } \\
\text { No. of patients }\end{array}$ & $\cdots$ & $\begin{array}{c}6-12 \\
2^{*}\end{array}$ & $\begin{array}{c}12-24 \\
4^{*}\end{array}$ & $\begin{array}{c}24+ \\
9\end{array}$ & $\begin{array}{c}24+ \\
2\end{array}$ & 17 \\
\hline
\end{tabular}

* Three patients had received regular intermittent steroid therapy for several years but had been converted to daily treatment 13,12 , and 6 months before the presen study. The remaining three patient
months before the present study.

hospital during the period of change in therapy. The maintenance dose of prednisolone was continued and baseline plasma corticosteroid concentrations were measured at 09.00 hours and 22.30 hours on three successive days. (Plasma corticosteroid concentrations were not measured at 09.00 hours in one child and at 22.30 hours in two children.) On the fourth day treatment with intramuscular corticotrophin (Acthar gel) was started, 20 units at 09.00 hours and at 21.00 hours.

Plasma corticosteroid concentrations were measured on alternate days thereafter at 13.00 hours. When the plasma corticosteroid concentration exceeded $15 \mu \mathrm{g} / 100 \mathrm{ml}$ the prednisolone therapy was stopped. Corticotrophin was then given in a dose of 20 units once daily at 09.00 hours, and after 48 hours the plasma corticosteroid concentration was measured immediately preceding (zero time) and at 4,8 , and 12 hours after the corticotrophin injection. These values were called the "plasma cortisol profile."

Forty-eight hours later the injection of corticotrophin was omitted and a graded intravenous tetracosactrin (Synacthen) test was performed as described by Landon et al. (1967).

Treatment with corticotrophin was then continued and an insulin stress test (Malone et al., 1970) was performed about one month later. During the period of follow-up (20-36 months) this test was repeated at intervals in all patients who had a subnormal initial result. Our criterion for a normal response to hypoglycaemia was that the plasma cortisol should rise to a concentration of at least $20 \mu \mathrm{g} / 100 \mathrm{ml}$ and that there should be an increment in cortisol concentration greater than $7 \mu \mathrm{g} / 100 \mathrm{ml}$. The patients were also assessed clinically at intervals of four to six weeks and, at the time of each visit, the morning dose of corticotrophin was omitted so that plasma corticosteroid concentrations could be measured between 09.00 and 09.30 hours.

The plasma corticosteroid concentrations were assayed by the method of Mattingly (1962). Blood glucose concentrations were assayed by the method of Morley et al. (1968).

\section{Results}

Plasma Corticosteroid Concentrations before Starting Corticotrophin Therapy.-The results are shown in Fig. 1. The mean concentration at 09.00 hours was $2.3 \mu \mathrm{g} / 100 \mathrm{ml}$ and at 22.30 hours it was $1.3 \mu \mathrm{g} / 100 \mathrm{ml}$. In one child the concentration was $8.0 \mu \mathrm{g} / 100 \mathrm{ml}$ at 09.00 hours, but in this case long-term prednisolone had been given on alternate days.

Response to Corticotrophin Therapy.-Plasma corticosteroid concentrations exceeded $15 \mu \mathrm{g} / 100 \mathrm{ml}$ within five days of

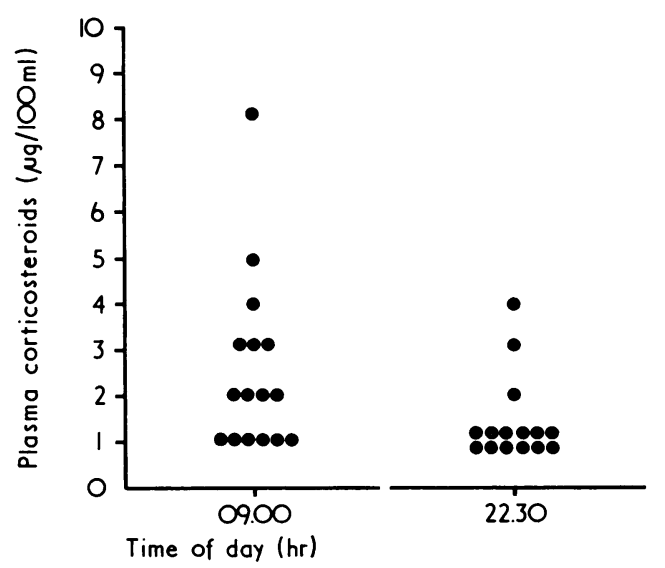

FIG. 1-Plasma cortisol concentrations before treatment with corticotrophin.

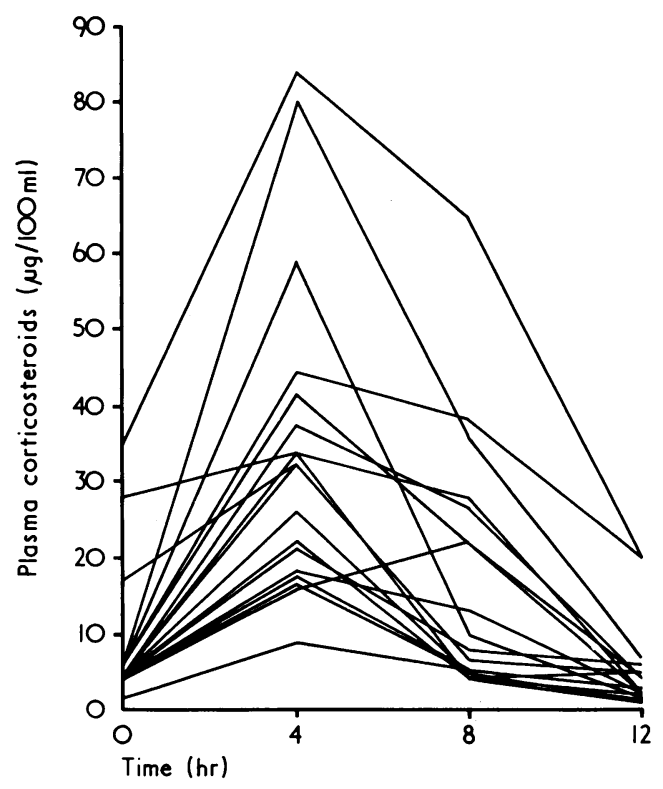

FIG. 2-Plasma cortisol profile.

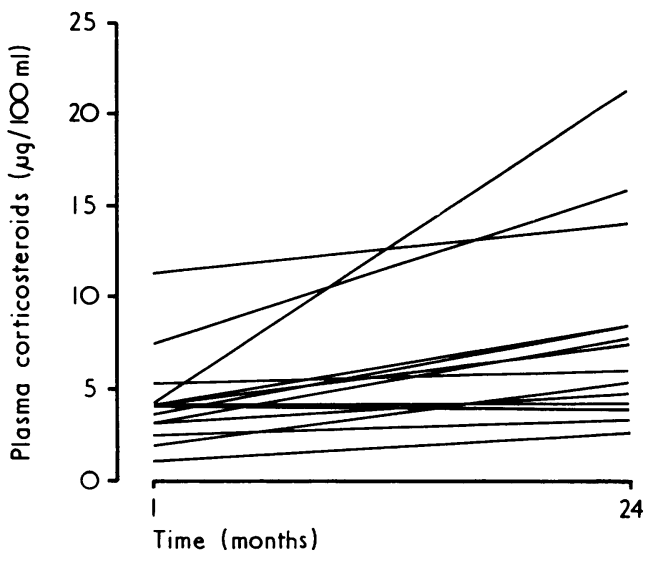

FIG. 3-Morning plasma cortisol concentrations one month and 24 months after starting corticntrophin. 
starting corticotrophin in 14 out of 17 children. In the remaining three the times taken were 10,14, and 54 days. The "cortisol profile" results are shown in Fig. 2. In 16 out of 17 children studied the maximum corticosteroid concentration was found four hours after the injection. The plasma corticosteroid concentrations between 09.00 and 09.30 hours one month and 24 months after corticotrophin therapy was started are shown in Fig. 3.

Graded Intravenous Tetracosactrin Tests.-The results of the graded intravenous tetracosactrin tests are shown in Fig. 4.

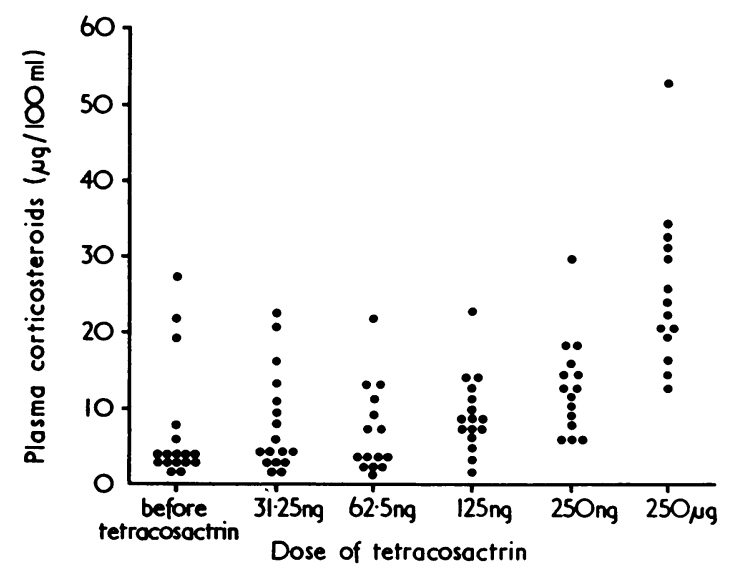

FIG. 4-Plasma cortisol concentrations after doubling doses of tetracosactrin intravenously.

The mean plasma corticosteroid concentrations were $6.5,8 \cdot 2$, $6.4,8.0,12 \cdot 4$, and $22.2 \mu \mathrm{g} / 100 \mathrm{ml}$.

Insulin-induced Hypoglycaemia Tests.-The plasma corticosteroid response to insulin-induced hypoglycaemia is shown in Table III. In four children the response was normal at the first test after converting to corticotrophin therapy (group 1), whereas in a further nine children a normal response occurred only after repeated testing (group 2). In one child there was no increment in plasma corticosteroid concentrations during seven separate tests (group 3).

TABLB III-Plasma Corticosteroid Response to Insulin-induced Hypoglycaemia

\begin{tabular}{|c|c|c|c|c|c|c|}
\hline \multirow[t]{2}{*}{ Group } & \multirow[t]{2}{*}{$\begin{array}{l}\text { No. of } \\
\text { Patients }\end{array}$} & \multirow[t]{2}{*}{$\begin{array}{c}\text { No. of } \\
\text { Tests }\end{array}$} & \multicolumn{2}{|c|}{$\begin{array}{c}\text { Mean Rise in Plasma } \\
\text { Corticosteroid } \\
(\mu \mathrm{g} / 100 \mathrm{ml})\end{array}$} & \multicolumn{2}{|c|}{$\begin{array}{c}\text { Mean Fall in Blood } \\
\text { Glucose } \\
(\mathrm{mg} / 100 \mathrm{ml})\end{array}$} \\
\hline & & & $\mathbf{A}$ & B & $\mathbf{A}$ & B \\
\hline$\ddot{\ddot{*}}$ & $\begin{array}{l}4 \\
9 \\
1\end{array}$ & $\begin{array}{r}4 \\
33 \\
7\end{array}$ & $\begin{array}{c}17 \cdot 7 \\
5 \cdot 5 \\
0\end{array}$ & $\overline{18 \cdot 1}$ & $\begin{array}{l}33 \cdot 2 \\
41 \cdot 3 \\
53\end{array}$ & $\begin{array}{l}\overline{48 \cdot 2} \\
64\end{array}$ \\
\hline
\end{tabular}

A = Initial test after conversion to corticotrophin. B = Final test after conversion to corticotrophin

Days in Hospital before and during Corticotrophin Therapy.The number of days 6 of the 17 patients spent in hospital while on prednisolone therapy and after conversion to corticotrophin are shown in Table IV.

TABLE IV-Time Spent in Hospital before and after Conversion to Corticotrophin

\begin{tabular}{|c|c|c|c|c|}
\hline \multirow[b]{2}{*}{$\begin{array}{l}\text { Case } \\
\text { No. }\end{array}$} & \multicolumn{2}{|c|}{ Before Corticotrophin } & \multicolumn{2}{|c|}{ During Corticotrophin } \\
\hline & $\begin{array}{l}\text { No. of Days in } \\
\text { Hospital* }\end{array}$ & $\begin{array}{c}\text { Percentage Time } \\
\text { in Hospital }\end{array}$ & $\begin{array}{c}\text { No. of Days in } \\
\text { Hospital* }\end{array}$ & $\begin{array}{l}\text { Percentage Time } \\
\text { in Hospital }\end{array}$ \\
\hline $\begin{array}{ll}1 & \cdots \\
2 & \cdots \\
3 & \cdots \\
4 & \cdots \\
5 & \cdots \\
6 & \cdots\end{array}$ & $\begin{array}{r}110 / 365 \\
134 / 240 \\
48 / 365 \\
45 / 365 \\
30 / 180 \\
24 / 365\end{array}$ & $\begin{array}{l}30 \\
56 \\
13 \cdot 2 \\
12 \cdot 3 \\
16 \cdot 6 \\
6 \cdot 6\end{array}$ & $\begin{array}{l}38 / 730 \\
26 / 7365 \\
21 / 365 \\
26 / 365 \\
19 / 180 \\
7 / 210\end{array}$ & $\begin{array}{r}5 \cdot 2 \\
7 \cdot 1 \\
5 \cdot 8 \\
7 \cdot 1 \\
10.5 \\
3 \cdot 3\end{array}$ \\
\hline
\end{tabular}

-Numerator = Duration of hospital admissions (days). Denominator = Total Numerator $=$ Duration of hospital ad
comparable period of observation (days).

\section{Discussion}

In this study the hypothalamo-pituitary-adrenal axis has been assessed in a group of asthmatic children before and after the treatment regimen was changed from long-term prednisolone to daily corticotrophin. The low plasma corticosteroid concentrations before conversion confirmed that suppression of the hypothalamo-pituitary-adrenal axis had occurred in the 16 patients assessed. Because of the dangers of adrenocortical insufficiency and the reported high incidence of status asthmaticus (11 out of 52) and death ( 3 out of 52) after withdrawal of long-term steroids (Friedman and Strang, 1966), prednisolone therapy was stopped only when the plasma corticosteroid concentration was higher than $15 \mu \mathrm{g} / 100 \mathrm{ml}$ four hours after 20 units of corticotrophin. With this regimen there was no exacerbation of asthmatic symptoms. The delay between starting corticotrophin therapy and achieving a plasma corticosteroid concentration higher than $15 \mu \mathrm{g} / 100 \mathrm{ml}$ might have been reduced by increasing the dose of corticotrophin (Young et al., 1957). When corticotrophin is given therapeutically, however, the dosage is commonly similar to that used in this study. In such circumstances it is important to realize that a small proportion of young asthmatic patients previously treated with oral steroids may have a considerably delayed adrenocortical response. For this reason we strongly recommend careful assessment of adrenocortical function by measurement of plasma corticosteroid concentrations when converting asthmatic subjects from long-term steroid therapy to corticotrophin.

Planning of long-term corticotrophin therapy should take into account the duration and degree of response to corticotrophin injection. The cortisol profiles which we performed showed that after 20 units of corticotrophin the response lasted for about 12 hours, the maximum concentration being higher than $15 \mu \mathrm{g} /$ $100 \mathrm{ml}$ in all but one patient. On the basis of these results we have used a regimen in which corticotrophin injections were given once daily so that the period of potential adrenocortical insufficiency between injections was kept short.

To assess the sensitivity of the adrenal cortex to direct stimulation, a graded intravenous tetracosactrin test was performed in 16 patients. Landon et al. (1967) found that in normal adults a rise in plasma corticosteroids occurred after a dose of $31.25 \mathrm{ng}$ of tetracosactrin intravenously. In our young patients the response threshold was raised in all but three subjects. It had been hoped that this test would give an indication of the dose of corticotrophin required to control the asthmatic symptoms of each patient, but, unlike Ansari et al. (1969), we found that there was little correlation between plasma corticosteroid concentrations and the clinical condition of the patient. Many of our patients had basal morning plasma corticosteroid concentrations below $5 \mu \mathrm{g} / 100 \mathrm{ml}$ without recurrence of asthmatic symptoms, and these low levels tended to persist during the period of follow-up (Fig. 3). On the other hand, Ansari et al. (1969) found that in a group of predominantly adult asthmatic subjects the morning plasma corticosteroid concentrations became normal in all 29 patients eight months after starting corticotrophin.

It has been suggested that long-term administration of corticotrophin might lead to suppression of pituitary function (Lancet, 1970), and Weaver (1969) criticized the use of tetracosactrin zinc complex on the basis that its prolonged use might suppress the hypothalamo-pituitary-adrenal axis. This led him to use corticotrophin on an intermittent basis.

In all but three of the present patients the basal plasma corticosteroid concentrations remained low for as long as 24 months after starting corticotrophin treatment. On the other hand, the response to hypoglycaemia was normal in four subjects about one month after starting corticotrophin and returned to normal in a further nine subjects (Table III). This suggests that the basal plasma corticotrophin concentrations remained lower than normal but that following insulin-induced hypoglycaemia a normal increment in plasma corticotrophin concentration had occurred. While adrenocortical secretion is controlled by the 
combined function of all components of the hypothalamopituitary-adrenal axis, adrenocortical function is still often assessed solely by the increment in plasma corticosteroid concentration produced by exogenous corticotrophin (Sampson et al., 1962; Wood et al., 1965; Ansari et al., 1969). We have emphasized that assessment of the response to stress is essential (Malone et al., 1970), and in the studies reported here it is clear that without this assessment incorrect conclusions regarding the integrity of the hypothalamo-pituitary-adrenal axis might have been reached. In 13 out of 14 asthmatic children daily corticotrophin treatment does not seem to have produced suppression of pituitary function in terms of ability to respond to hypoglycaemic stress.

The average time taken for a normal response to hypoglycaemia to develop in these patients was 14.7 months (range 3-24 months). This time is rather longer than that found in adult subjects by Livanou et al. (1967). They found that after withdrawal of steroids, and without using corticotrophin therapy, only one patient (with an adrenocortical adenoma) had an abnormal response to hypoglycaemia more than 12 months after withdrawal of steroid therapy. One patient in the present study, who took two months to show a plasma corticosteroids response to corticotrophin, still had an abnormal corticosteroid response to hypoglycaemia 36 months after conversion to corticotrophin.

Assessment of time spent in hospital was possible only in six patients who had sufficient hospital admissions before and after the change in treatment regimen. From the results obtained (Table IV) the control of asthmatic symptoms was more satisfactory on corticotrophin, but the group studied was small and there may have been an element of bias, since after starting corticotrophin all the patients were seen regularly by only one physician. This could have resulted in a diminished admission rate, although it is less likely that the duration of stay in hospital would have been altered appreciably.

\section{References}

Ansari, Z. H., Clark, P. A., and Maher-Loughnan, G. P. (1969). British Fournal of Diseases of the Chest, 63, 215.

Friedman, M., and Strang, L. B. (1966). Lancet, 2, 568.

James, V. H. T. (1970). Pharmacologica Clinica, 2, 182.

Lancet, 1970, 2, 558.

Landon, J., James, V. H. T., Wharton, M. J., and Friedman, M. (1967). Lancet, 2,697 .

Livanou, T., Ferriman, D., and James, V. H. T. (1967). Lancet, 2, 856.

Malone, D. N. S., Grant, I. W. B., and Percy-Robb, I. W. (1970). Lancet, 2, 733.

Mattingly, D. (1962). Fournal of Clinical Pathology, 15, 374.

Maunsell, K., Bruce Pearson, R. S., and Livingstone, J. L. (1968). British

Medical fournal, 1, 661.
Morley, G., Dawson, A., and Marks, V. (1968). Proceedings of the Association of Clinical Biochemists, 5, 42.
o.

Sampson, P. A., Winstone, N. E., and Brooke, B. N. (1962). Lancet, 2, 322.

Schwarz, H. (1959). Canadian Medical Association fournal, 81, 159.

Weaver, J. A. (1969). British Medical fournal, 1, 639.

Wood, J. B., Frankland, A. W., James, V. H. T., and Landon, J. (1965). Lancet, 1, 243.

Young, I. I., De Filippis, V., Meyer, F. L., and Wolfson, W. Q. (1957). Archives of Internal Medicine, 100, 1 .

\title{
Vitamin D Intoxication Treated with Porcine Calcitonin
}

\author{
R. M. BUCKLE, T. R. GAMLEN, I. M. PULLEN
}

British Medical fournal, 1972, 3, 205-207

calcitonin of three hypercalcaemic patients with vitamin $\mathrm{D}$ intoxication.

\section{Summary}

Porcine calcitonin was used to treat three patients with hypercalcaemia due to vitamin $D$ intoxication. In two patients a rapid and sustained fall to normal in serum calcium occurred within three days, in the third patient normocalcaemia was achieved in seven days. In view of its rapid and sustained effect calcitonin may be of value in the urgent treatment of hypercalcaemia due to vitamin D intoxication.

\section{Introduction}

Poisoning with vitamin $\mathrm{D}$ is now less frequent than formerly when vitamin $D$ was prescribed for a variety of skin and arthritic disorders. Yet cases still occur and the associated hypercalcaemia may be life-threatening. The patient becomes anorexic, nauseated, develops mental impairment, and may lapse into coma, while cardiac arrhythmias and renal failure may occur. In severe cases urgent treatment of the hypercalcaemia is required.

The calcium-lowering hormone, calcitonin, has been shown to be active in man (Milhaud, Bourichin, Moukhtar, and Perault-Staub, 1965; Foster, Joplin, MacIntyre, Melvin, and Slack, 1966), and we report here the treatment with porcine

General and Western Hospitals, Southampton

R. M. BUCKLE, M.D., F.R.C.P., Consultant Physician

I. M. PULLEN, M.B., B.S., Senior House Officer

\section{Case 1}

A 69-year-old woman with hypoparathyroidism was admitted to hospital in a drowsy and confused state. She had been unwell for three weeks, complaining of anorexia, constipation, and increased thirst. She had previously had a subtotal thyroidectomy and was first seen one year previously with hypocalcaemia. Her initial investigations showed a serum calcium of $3.8 \mathrm{mg} / 100 \mathrm{ml}$, phosphate $8.8 \mathrm{mg} / 100$, and an alkaline phosphatase of $7-9 \mathrm{~K} . \mathrm{A}$. units. The plasma proteins were $8.0 \mathrm{~g} / 100 \mathrm{ml}$ (albumin $3.7 \mathrm{~g}$, globulin $4.3 \mathrm{~g}$ ) and the blood urea was $40 \mathrm{mg} / 100 \mathrm{ml}$. While hypocalcaemic her plasma did not contain any detectable immunoassayable parathyroid hormone (Buckle, 1968). A diagnosis of hypoparathyroidism was made and she was treated with oral calcium and calciferol $1.25 \mathrm{mg}$ (50,000 units) a day. The plasma calcium rose and stabilized at concentrations of $8.9-9.6 \mathrm{mg} / 100 \mathrm{ml}$ and the dosage of calciferol was reduced to $1.25 \mathrm{mg}(50,000$ units) twice a week. It was later ascertained that for four weeks before admission she had mistakenly taken calciferol $7.5 \mathrm{mg}$ (300,000 units) a day.

On examination she was lethargic and mentally confused. There was muscular hypotonia and the tendon reflexes were depressed. Her urine contained protein. The initial serum calcium was $15.1 \mathrm{mg} / 100 \mathrm{ml}$, and a repeat eight hours later was $15.8 \mathrm{mg} / 100$ $\mathrm{ml}$, plasma phosphate $5.3 \mathrm{mg} / 100 \mathrm{ml}$, and the alkaline phosphatase 8 K.A. units. The plasma proteins were $7 \cdot 3 \mathrm{~g} / 100 \mathrm{ml}$ (albumin $3.6 \mathrm{~g}$. globulin $3.7 \mathrm{~g}$ ). The blood urea was $196 \mathrm{mg} / 100 \mathrm{ml}$.

Progress-Porcine calcitonin 40 M.R.C. units was given intravenously twice daily by injection over five minutes and, in addition, a continuous intravenous infusion of porcine calcitonin 120 M.R.C. units in $500 \mathrm{ml}$ of normal saline was administered every 12 hours (Fig. 1). One hour after the first injection of calcitonin 